\title{
Pin1 inhibits PP2A-mediated Rb dephosphorylation in regulation of cell cycle and S-phase DNA damage
}

\author{
Y Tong ${ }^{1,5}, \mathrm{H} \mathrm{Ying}^{2,5}, \mathrm{R} \mathrm{Liu}^{1}, \mathrm{~L} \mathrm{Li}{ }^{3}$, J Bergholz ${ }^{1}$ and Z-X Xiao ${ }^{\star, 1,4}$
}

Inactivation of the retinoblastoma protein $(\mathrm{Rb})$ has a key role in tumorigenesis. It is well established that $\mathrm{Rb}$ function is largely regulated by a dynamic balance of phosphorylation and dephosphorylation. Although much research has been done to understand the mechanisms and function of RB phosphorylation, the regulation of Rb dephosphorylation is still not well understood. In this study, we demonstrate that Pin1 has an important role in the regulation of Rb function in cell cycle progression and S-phase checkpoint upon DNA damage. We show that the Rb C-pocket directly binds to the Pin1 WW domain in vitro and in vivo, and that the phosphorylation of Rb C-pocket by G1/S Cyclin/Cyclin-dependent kinase complexes is critical for mediating this interaction. We further show that $\mathrm{Rb}$-mediated cell cycle arrest and $\mathrm{Rb}$-induced premature cellular senescence are effectively inhibited by Pin1 expression. In addition, DNA damage induces Rb dephosphorylation in a PP2A-dependent manner, and this process is inhibited by Pin1. Furthermore, the overexpression of Pin1 promotes Rb hyperphosphorylation upon S-phase DNA damage. Importantly, both the Pin1 WW domain and isomerase activity are required for its effect on S-phase checkpoint. Moreover, the overexpression of Pin1 is correlated with Rb hyperphosphorylation in breast cancer biopsies. These results indicate that Pin1 has a critical role in the modulation of $\mathrm{Rb}$ function by the regulation of $\mathrm{Rb}$ dephosphorylation, which may have an important pathological role in cancer development.

Cell Death and Disease (2015) 6, e1640; doi:10.1038/cddis.2015.3; published online 12 February 2015

The Retinoblastoma protein (Rb), encoded by the RB1 gene, is a critical regulator of cell cycle progression and has an important role in numerous aspects of biology, including DNA damage response, apoptosis, senescence and differentiation. ${ }^{1-5} \mathrm{Rb}$ is an important regulator of the cell cycle that acts predominantly by binding to and inhibiting the gene transactivation by E2F transcription factors, which would otherwise induce the expression of genes that enhance cell cycle progression. $\mathrm{Rb}$ binds $\mathrm{E} 2 \mathrm{~F}$ proteins through the $\mathrm{Rb}$ large pocket domain (RbLP), which includes the two conserved $A$ and $B$ domains as well as a $C$-terminal pocket $(R b C)$. The $A$ and $B$ domains, referred together as the Rb small pocket (RbSP), mediate binding to specific regulatory proteins and oncoproteins containing a conserved LXCXE motif. ${ }^{6-9}$ The Rb $\mathrm{C}$-pocket has been shown to be essential for mediating $\mathrm{Rb}$ interaction with $\mathrm{E} 2 \mathrm{~F}^{10}{ }^{10}$ In addition, the RbC directly binds to MDM2, which inhibits Rb by competing with E2F for binding, as well as by promoting $\mathrm{Rb}$ degradation by the proteasome. ${ }^{11,12}$

The biological function of $\mathrm{Rb}$ is critically regulated by protein phosphorylation. Hypophosphorylated $\mathrm{Rb}$ interacts with $\mathrm{E} 2 \mathrm{~F}$, thereby acting as the biologically active form of $\mathrm{Rb}$.
Conversely, hyperphosphorylated $\mathrm{Rb}$ is unable to bind $\mathrm{E} 2 \mathrm{~F}$ proteins, thereby allowing E2F to promote cell cycle progression. ${ }^{1,13}$ During cell cycle, Rb phosphorylation is primarily conducted by Cyclin/Cyclin-dependent kinase (CDK) complexes; ${ }^{414-16}$ Cyclin D/CDK4/6 are the initial kinases to phosphorylate Rb, followed by Cyclin E/CDK2 and then by Cyclin A/CDK2. The majority of Cyclin/CDK phosphorylation sites are found in the RbC. ${ }^{4,17}$ Dephosphorylation of $\mathrm{Rb}$ by protein phosphatase 1 (PP1) and protein phosphatase 2A (PP2A) during mitotic exit returns $R b$ to a hypophosphorylated state, in keeping with the required regulation of a new cell cycle. ${ }^{18-20}$

$\mathrm{Rb}$ has a pivotal role in regulating cell cycle progression during normal and stress conditions. S-phase DNA damage induced by irradiation, oxidative stress or by chemotherapeutic agents such as cisplatin or etoposide, leads to rapid PP2A-dependent $\mathrm{Rb}$ dephosphorylation and activation, thus resulting in the suppression of DNA synthesis and cell cycle arrest. Moreover, PP2A has been shown to enhance $\mathrm{Rb}$ function toward inhibiting DNA replication via the recruitment of hypophosphorylated $\mathrm{Rb}$ to replication control sites. $^{19-22}$

\footnotetext{
${ }^{1}$ Center of Growth, Metabolism and Aging, Key Laboratory of Biological Resources and Ecological Environment of Ministry of Education, College of Life Sciences and State Key Laboratory of Biotherapy, Sichuan University, Chengdu 610064, China; ${ }^{2}$ The University of Texas MD Anderson Cancer Center, Houston, TX 77030, USA; ${ }^{3}$ Cancer Center, West China Hospital, Sichuan University, Chengdu 610041, China and ${ }^{4}$ Department of Biochemistry, Boston University School of Medicine, Boston, MA 02118, USA

${ }^{*}$ Corresponding author: Z-X Xiao, Center of Growth, Metabolism and Aging, Key Laboratory of Biological Resources and Ecological Environment of Ministry of Education, College of Life Sciences and State Key Laboratory of Biotherapy, Sichuan University, Chengdu 610064, China. Tel/Fax: +86 8541-5509; E-mail: bmc605@hotmail.com or jimzx@scu.edu.cn

${ }^{5}$ These authors contributed equally to this work.

Abbreviations: Rb, Retinoblastoma protein; RbLP, Rb large pocket domain; RbC, Rb C-terminal pocket domain; RbSP, Rb small pocket domain; CDK, Cyclin-dependent kinases; PP1, Protein phosphatase 1; PP2A, Protein phosphatase 2A; PPlase, Peptidyl-prolyl isomerase; pS/T-P, phosphorylated serine/threonine-proline motif; S/T-P, Serine/threonine-proline motif; MEF, Mouse embryonic fibroblast; BSA, Bovine serum albumin; SA- $\beta$-Gal, Senescence-associated $\beta$-Galactosidase; St, SV40 small $t$ antigen; RDS, Radioresistant DNA synthesis assays; PBS, Phosphate-buffered saline

Received 04.6.14; revised 31.12.14; accepted 02.1.15; Edited by J Chipuk
} 
The prolyl isomerase Pin1 binds to and modulates numerous proteins involved in cell proliferation, differentiation, DNA damage response, apoptosis and development. ${ }^{23,24}$ Pin1 consists of an N-terminal WW domain for specific protein interaction and a C-terminal catalytic peptidyl-prolyl isomerase (PPlase) domain. Pin1 specifically catalyzes cis to trans isomerization of proline residues in strictly phosphorylated serine/threonine-proline moieties ( $\mathrm{pS} / \mathrm{T}-\mathrm{P})$, thus affecting substrate function, stability, subcellular localization and/or interacting properties. ${ }^{25-27}$

In this study, we describe a molecular mechanism by which Pin1 modulates $\mathrm{Rb}$ function in cell cycle progression and in DNA damage-induced S-phase checkpoint. We show that Pin1 specifically binds to hyperphosphorylated $\mathrm{Rb}$ and inhibits PP2A-mediated $\mathrm{Rb}$ dephosphorylation. In addition, Rbmediated cell cycle arrest and Rb-induced premature cellular senescence are effectively inhibited by Pin1 expression. Similarly, Pin1 deficiency leads to abnormal Rb dephosphorylation upon S-phase DNA damage, resulting in a defective S-phase checkpoint. Hence, this study suggests a novel molecular mechanism in which the Pin1-mediated modulation of $\mathrm{Rb}$ phosphorylation has an important role in cancer development.

\section{Results}

Pin1 specifically binds to the $\mathbf{R b}$ C-pocket. The $\mathrm{Rb} C$ terminus contains several S/T-P motifs, which are putative Pin1-binding sites. We therefore examined whether Pin1 can physically interact with $\mathrm{Rb}$ using a pull-down assay. As shown in Figure 1a, both GST-Pin1 and GST-Pin1-WW effectively pulled down endogenous $\mathrm{Rb}$ from osteosarcoma U2-OS cell lysates, whereas GST-Pin1-PPlase domain was unable to bind $\mathrm{Rb}$. In addition, point mutations in the Pin1 WW domain at W34A or Y23A, two amino-acid residues critical for Pin1 substrate binding, ${ }^{28}$ abolished Pin1-Rb interaction (Figure 1a). These results indicate that $R b$ interacts specifically with the Pin1 WW domain.

To further define the Pin1-Rb interaction, we expressed various $\mathrm{Rb}$ protein constructs in U2-OS cells and subjected the cell lysates to GST-Pin1 pull down. As shown in Figure 1b, Pin1 interacted with full-length $\mathrm{Rb}$ as well as with the RbLP (including $A, B$ and $C$ domains), but not with the $R b$ small pocket (RbSP, including $A$ and $B$ domains), suggesting that the $\mathrm{Rb}$ C-pocket $(\mathrm{RbC})$ is important for Pin1 interaction. Indeed, the $\mathrm{RbC}$ alone interacted well with Pin1, indicating that the $\mathrm{Rb}$ $\mathrm{C}$-pocket is necessary and sufficient for Rb-Pin1 interaction. Moreover, we observed endogenous Pin1-Rb co-localization by immunofluorescence in non-small-cell lung carcinoma H1299 cells (Figure 1c), as well as binding in vivo by co-immunoprecipitation in $\mathrm{H} 1299$ and U2-OS cells (Figures 1d and e).

Pin1-Rb interaction is induced by G1-S Cyclin-mediated Rb phosphorylation. CDKs are primarily responsible for the phosphorylation of $\mathrm{Rb}$. As the majority of CDK phosphorylation sites are within the $\mathrm{Rb} \mathrm{C}$-pocket, ${ }^{4,17}$ we examined whether CDK-mediated $\mathrm{Rb}$ phosphorylation signals for Pin1-Rb interaction. Pin1 preferentially bound to the hyperphosphorylated, slower migrating Rb species. Treatment of U2-OS cells with roscovitine, a potent CDK inhibitor, resulted in significant accumulation of hypophosphorylated $\mathrm{Rb}$, as shown by the faster migration of hypophosphorylated $\mathrm{Rb}$ species. Roscovitine treatment abrogated Pin1-Rb interaction, indicating that $\mathrm{Rb}$ phosphorylation is required for Pin1-Rb binding, and that Pin1 preferentially binds to hyperphosphorylated $\mathrm{Rb}$ but not to hypophosphorylated $\mathrm{Rb}$ (Figure 2a).

The $\mathrm{Rb} \mathrm{C}$-pocket contains seven pS/T-P motifs (Figure $2 \mathrm{~b}$ ). To investigate the role of these putative Pin1-binding sites in Pin1-Rb interaction, we expressed wild-type (WT) or mutant RbLP in U2-OS cells and compared their ability to bind Pin1. Double substitution of $\mathrm{S} 807$ and $\mathrm{S} 811$ by alanine residues (RbLP-2S) virtually abolished Pin1-Rb interaction. Likewise, combined T821A and T826A mutations (RbLP-2T) significantly inhibited Pin1-Rb binding, albeit to a lesser degree. Moreover, RbLP-7A, in which all seven serine or threonine residues were substituted by alanine, completely lost interaction with Pin1 (Figure 2c).

Next we examined the effect of specific Cyclin/CDK complexes on Rb-Pin1 interaction. We co-transfected Saos2 cells with $\mathrm{Rb}$ and various Cyclin-expressing plasmids, and subjected the cell lysates to GST-Pin1 pull-down assays followed by immunoblotting for Rb. We chose to use Saos-2 cells because they are Rb-null and exhibit low levels of endogenous CDK activity. As shown in Figure 2d, the coexpression of $\mathrm{Rb}$ with Cyclin $\mathrm{D} 1$, Cyclin $\mathrm{E}$ or Cyclin $\mathrm{A}$ dramatically increased Pin1-Rb interaction, whereas the coexpression of Cyclin B1 had little effect, despite comparable levels of protein expression. These data indicate that the phosphorylation of Rb by G1- and S-phase Cyclin-associated kinases is a crucial signal for Rb-Pin1 interaction.

Pin1 inhibits PP2A-mediated Rb dephosphorylation. As our results showed that Pin1 binds to hyperphosphorylated $\mathrm{Rb}$, we investigated whether the Pin1-Rb interaction affects $\mathrm{Rb}$ phosphorylation. As shown in Figure 3a, Pin1-deficient mouse embryonic fibroblast (MEF) cells exhibited a clear decrease in the hyperphosphorylated Rb species at Ser807 and Ser811. Furthermore, Pin1 ablation resulted in increased hypophosphorylated Rb levels in H1299 cells (Figure 3b). Hypophosphorylated $\mathrm{Rb}$ associates tightly with the nuclear envelope and requires high salt concentrations for dissociation, whereas hyperphosphorylated $\mathrm{Rb}$ is soluble in lower salt concentrations. $^{29}$ Thus, to further examine the effect of Pin1 on $\mathrm{Rb}$ phosphorylation, we treated human nontransformed mammary epithelial MCF-10A cells expressing Pin1 or a vector control with or without extraction buffer containing $0.1 \%$ Triton-X-100 and $250 \mathrm{mM} \mathrm{NaCl}$. Treatment of Pin1expressing cells with extraction buffer resulted in $\mathrm{Rb}$ dissociation from the nucleus to a much greater extent than in control cells (Figure $3 c$ ), indicating that Rb binds less tightly to the nuclear matrix upon Pin1 expression. Together these data indicate that Pin1 is important in maintaining hyperphosphorylation of $\mathrm{Rb}$.

As it has been shown that Pin1 regulates PP2A activity, ${ }^{26,30,31}$ and that PP2A is important for $\mathrm{Rb}$ dephosphorylation, ${ }^{19,20}$ we performed in vitro dephosphorylation experiments to examine the effect of Pin1 on 
a

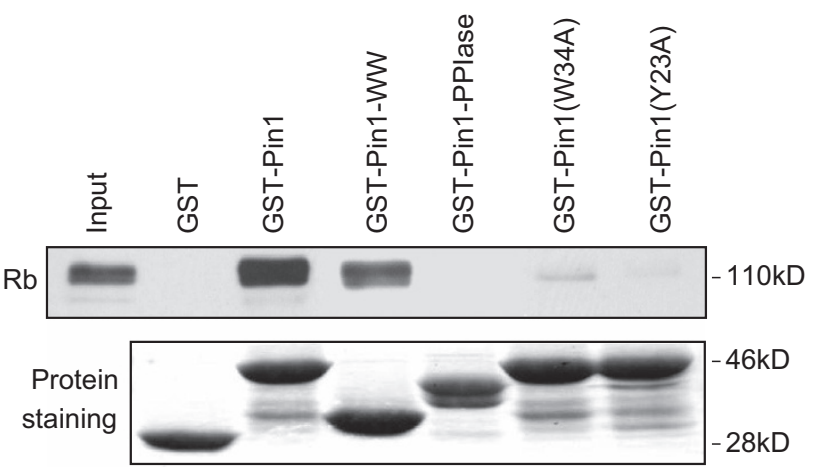

b

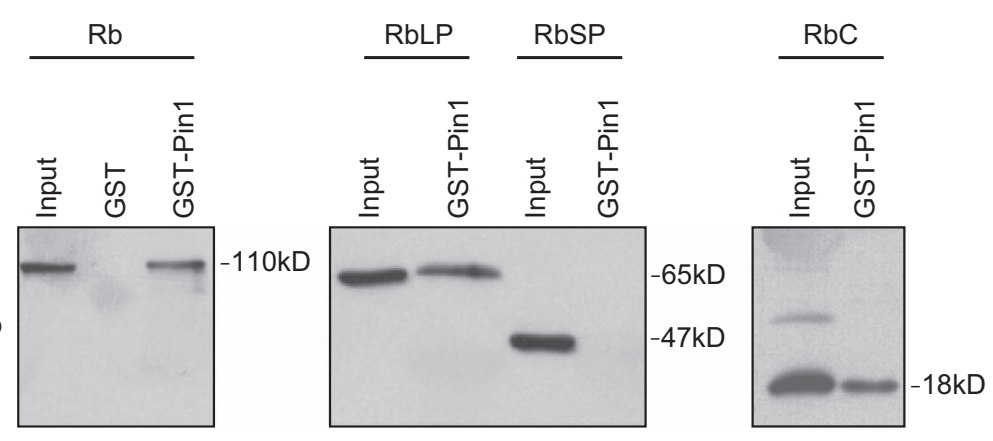

c

$\mathrm{Rb}$

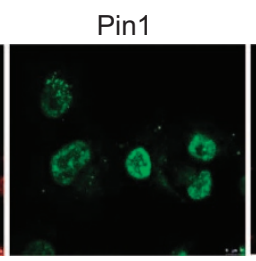

Merge
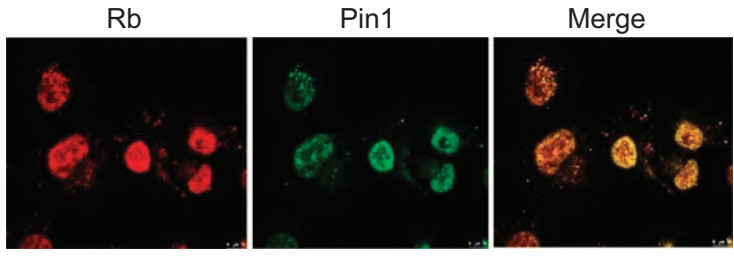

d

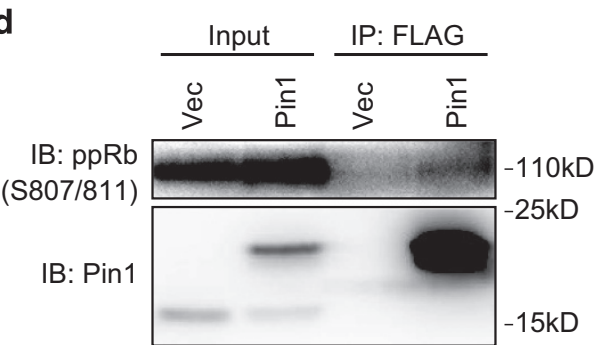

e

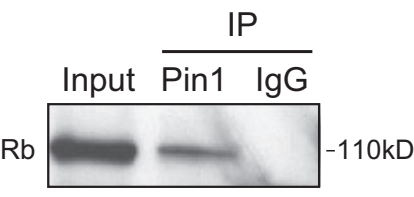

Figure 1 The Pin1 WW domain directly binds to the hyperphosphorylated Rb C-pocket. (a) U2-OS cell lysates were incubated with full-length, truncated or mutant Pin1-GST fusion constructs and subsequently subjected to GST pull-down assay, as shown. Proteins were separated by SDS-PAGE and immunoblotted with an Rb-specific antibody (top panel). Comparable levels of input GST or GST fusion proteins are shown by Coomassie blue staining (lower panel). (b) U2-OS cells were transiently transfected with full-length $\mathrm{Rb}, \mathrm{RbLP}, \mathrm{Rb}$ small pocket (RbSP) or Rb C-pocket (RbC). Total protein $(500 \mu \mathrm{g})$ was subjected to GST pull-down assay using recombinant GST-Pin1 or GST as a control and then analyzed by western blotting for $\mathrm{Rb}$ binding. Total protein $(10 \mu \mathrm{g})$ from each cell lysate was directly loaded as input controls. (c) H1299 cells were subjected to immunofluorescence, as shown. (d) Cell lysates from H1299 cells stably expressing FLAG-Pin1 or pLVX vector were subjected to immunoprecipitation with anti-FLAG M2 Affinity Gel, and immunoblotted for phosphorylated Rb (pRb) at Ser807/811 (S807/811) or Pin1, as shown. (e) U2-OS cell lysates were subjected to immunoprecipitation with a Pin1specific antibody or a control lgG, and immunoblotted for $\mathrm{Rb}$, as shown

PP2A-mediated Rb dephosphorylation. RbC fragments were in vitro phosphorylated and radiolabeled using $\left[{ }^{32} \mathrm{P}\right]$ by Cyclin E/CDK2, preincubated with WT or mutant Pin1, and incubated with PP2A for the indicated time intervals, followed by subsequent SDS-polyacrylamide gel electrophoresis (SDSPAGE) and autoradiography. Okadaic acid, which specifically inhibits PP2A activity at low concentrations, ${ }^{32}$ or bovine serum albumin (BSA) were used in parallel as controls. As shown in Figure $3 \mathrm{~d},\left[{ }^{32} \mathrm{P}\right]$-labeled $\mathrm{RbC}$ was rapidly dephosphorylated by
PP2A when preincubated with BSA, whereas preincubation with okadaic acid completely blocked Rb dephosphorylation. Strikingly, dephosphorylation of Rb by PP2A was significantly inhibited by WT Pin1, but not by the mutant derivatives. These results indicate that Pin1 is capable of inhibiting PP2Amediated $\mathrm{Rb}$ dephosphorylation in vitro.

Pin1 inhibits Rb-mediated cell cycle arrest and Rb-induced senescence. As our data show that Pin1 
a

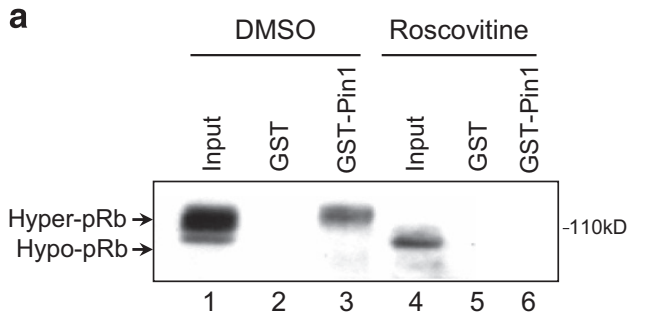

b

C

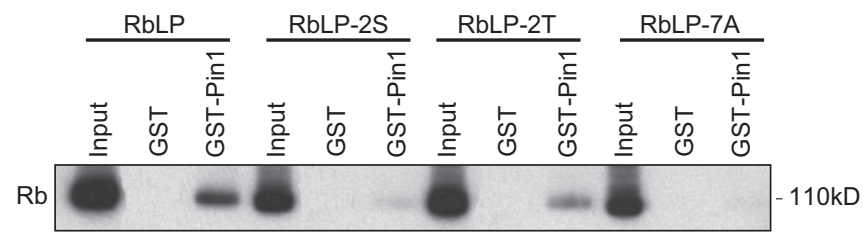

d

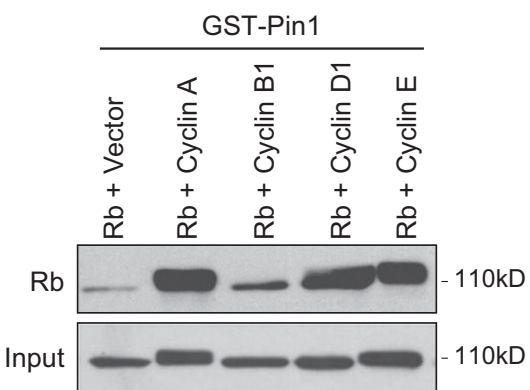

Figure 2 Pin1-Rb interaction is induced by G1-S Cyclin-mediated phosphorylation. (a) U2-OS cells were treated with vehicle (dimethyl sulfoxide, DMSO) or $30 \mu \mathrm{M}$ roscovitine for $18 \mathrm{~h}$. Cell lysates ( $500 \mu \mathrm{g}$ total protein) were pulled down by GST-Pin1, followed by western blotting for Rb. Total protein ( $30 \mu \mathrm{g}$ ) was loaded as an input control. Hyper-pRb, hyperphosphorylated Rb; Hypo-pRb, hypophosphorylated Rb. (b) Diagram of RbLP highlighting seven pS/T-P putative Pin1-binding sites within the Rb C-pocket $(\mathrm{RbC})$, as well as two double-point mutations to Ala (S807A;S811A, denominated 2S, and T821A;T826A, denominated 2T) and mutation of all Ser or Thr residues to Ala residues (7A) used for RbC-Pin1-binding studies. (c) U2-OS cells were transfected with WT or mutant RbLP. Cell lysates were subjected to GST-Pin1 pull-down assay and western blotted for Rb to assess binding. (d) Saos-2 cells were co-transfected with Rb along with Cyclin A, Cyclin B1, Cyclin D1, Cyclin E or a vector control, as shown. Cell lysates were subjected to GST-Pin1 pull down followed by western blotting for $\mathrm{Rb}$

inhibits $\mathrm{Rb}$ dephosphorylation, thereby maintaining $\mathrm{Rb}$ hyperphosphorylated, which is unable to bind E2F, we investigated the effect of Pin1 on Rb function toward inhibiting E2F activity. To this end, we used a luciferase reporter (DHFR-Luc) driven by the promoter of dihydrofolate reductase, which is a bona fide downstream target of E2F. We cotransfected DHFR-Luc with either WT Pin1 or Pin1-W34A into Rb-positive U2-OS cells, followed by luciferase activity assays. WT Pin1, but not Pin1-W34A, significantly stimulated E2F reporter activity in U2-OS cells. On the other hand, the ectopic expression of Pin1 in Rb-null Saos-2 cells failed to induce E2F reporter activity (Figure 4a). To assess the biological significance of this regulation, we silenced $\mathrm{Rb}$ and/ or Pin1 expression in $\mathrm{H} 1299$ cells. Again, Pin1 ablation led to increased hypo-pRb and decreased hyper-pRb levels (Figure 4b). Flow cytometry analysis of these cells showed that Pin1 knockdown resulted in G1 cell cycle arrest, which was effectively reverted upon concomitant $\mathrm{Rb}$ knockdown (Figure 4c). Moreover, the ectopic Rb expression in Saos-2 cells (Rb-null and p53 null) has been shown to induce premature cellular senescence. ${ }^{33}$ In keeping with these observations, $\mathrm{Rb}$ expression in Saos-2 cells led to an increased cellular senescence, as manifested by flat and enlarged cell morphology (Figure 4d), and increased senescence-associated $\beta$-Galactosidase (SA- $\beta$-Gal) activity (Figure 4e). Notably, concomitant Pin1 expression in Rbexpressing cells significantly reversed these effects, whereas mutant Pin1(W34A) was unable to affect Rb-induced cellular senescence (Figures $4 d$ and e). These data suggest that Pin1 inhibits Rb-mediated cell cycle arrest and Rb-induced senescence.

Pin1 modulates Rb phosphorylation during cell cycle progression. Rb has an important role at the S-phase checkpoint in cellular response to DNA damage. Upon $\gamma^{-}$ irradiation or oxidative stress, $\mathrm{Rb}$ is activated via dephosphorylation, resulting in blockage of DNA synthesis and S-phase cell cycle arrest. ${ }^{19,20}$ As Pin1 modulates $\mathrm{Rb}$ phosphorylation, we investigated the role of Pin1 in the regulation of $\mathrm{Rb}$ phosphorylation during S-phase checkpoint control. WT or Pin $1^{-/-}$MEF cells were synchronized at S-phase by treatment with aphidicolin, which led to increased hyperphosphorylated $\mathrm{Rb}$ in both WT and Pin1 $1^{-1-}$ MEFs (Figure 5a, lanes 2 and 8), indicating that $\mathrm{Rb}$ was hyperphosphorylated during S-phase. $\gamma$-Irradiation of S-phase WT MEFs resulted in $\mathrm{Rb}$ dephosphorylation at $8 \mathrm{~h}$ post irradiation. In contrast, $\mathrm{Rb}$ dephosphorylation in Pin $1^{-/}$MEFs was evident as early as $2 \mathrm{~h}$ post irradiation, yielding markedly 
a

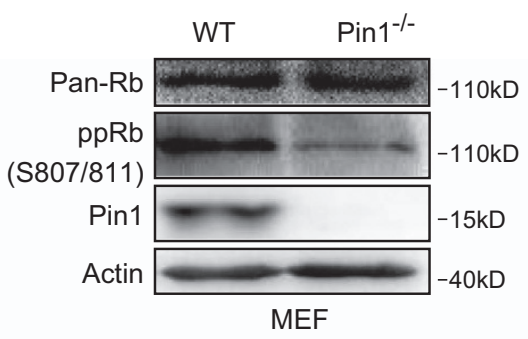

C

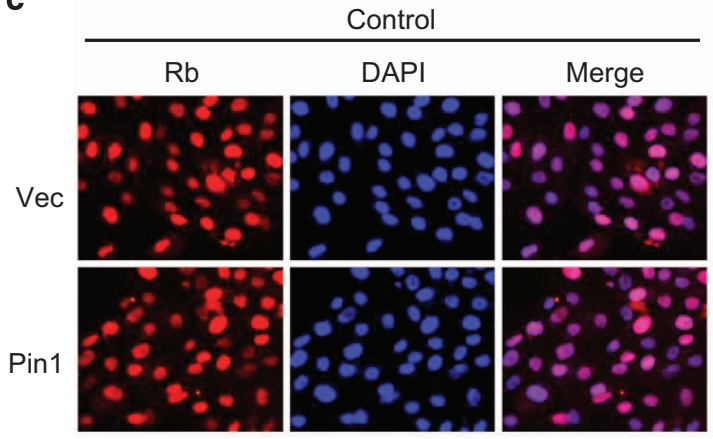

Extraction buffer

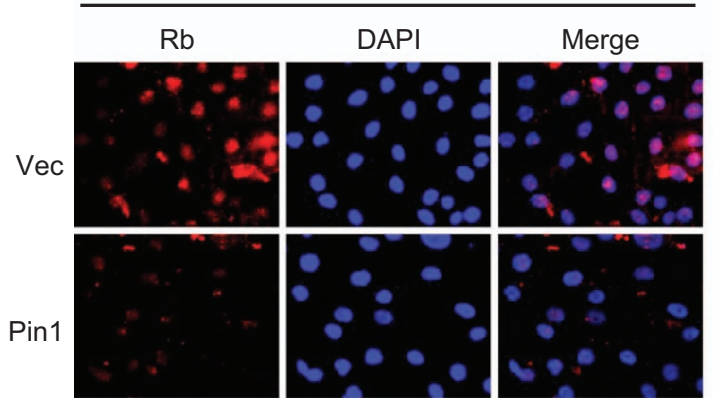

b

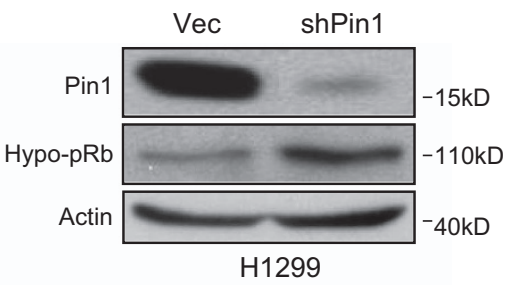

d

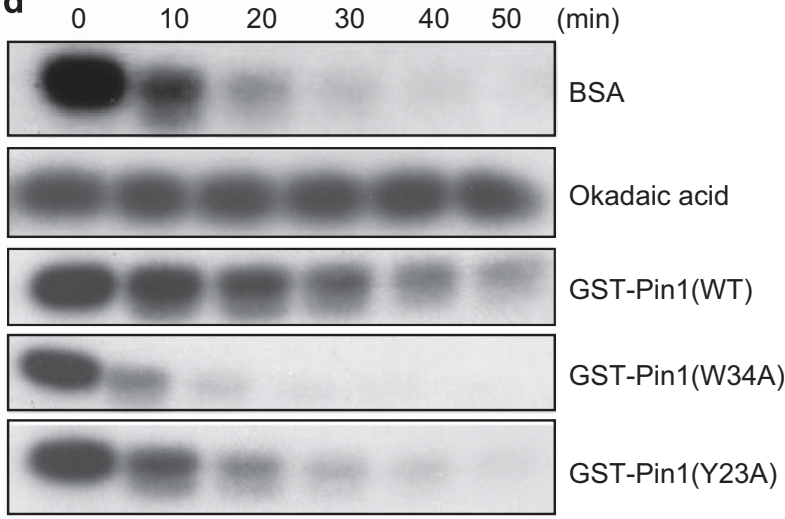

$\left[{ }^{32} \mathrm{P}\right]-\mathrm{Rb}-\mathrm{C}+\mathrm{PP} 2 \mathrm{~A}$

Figure 3 Pin1 inhibits Rb PP2a-mediated dephosphorylation. (a) WT or Pin1-deficient (Pin1 ${ }^{-1-}$ ) MEF cell lysates were subjected to western blot analysis for total Rb levels (Pan-Rb), phosphorylated Rb (pRb) at Ser807/811 (S807/811), Pin1 or Actin. (b) H1299 cells were infected with recombinant retrovirus expressing shRNA against Pin1 or a vector control. Whole-cell lysates were subjected to western blotting, as shown. (c) MCF-10A cells were stably transfected with a PLVXpuro vector control (Vec) or PLVX-Pin1 (Pin1). Stable cells were treated with or without extraction buffer and subsequently subjected to immunofluorescence for Rb and counterstained with DAPI. (d) Rb C-pocket (RbC) peptides were in vitro phosphorylated and labeled with Cyclin E/CDK2 complexes with $\gamma=\left[{ }^{32} \mathrm{P}\right]-\mathrm{ATP}$ as described in the Materials and Methods. [32 P]-labeled phosphorylated RbC peptides were then incubated with BSA, okadeic acid or WTor mutant GST-Pin1 fusion proteins, before incubation with PP2A for the indicated times. Dephosphorylation reactions were quenched by the addition of SDS sample buffer. Samples were analyzed by SDS-PAGE followed by autoradiography

decreased $\mathrm{Rb}$ phosphorylation levels in comparison with WT MEFs (Figures $5 a$ and b).

We examined whether the ectopic expression of Pin1 can affect Rb phosphorylation at S-phase checkpoint. IMR90 cells stably expressing either Pin1 or GFP were synchronized by hydroxyurea (HU) and then released into S-phase before exposure to $\gamma$-irradiation. As a control, we analyzed the cells expressing the SV40 small $t$ antigen (st), which has been shown to inhibit PP2A activity, thus leading to higher levels of hyperphosphorylated $\mathrm{Rb}^{34,35} \quad \gamma$-Irradiation dramatically reduced hyperphosphorylated $\mathrm{Rb}$. Expression of SV40 st led to significantly increased hyperphosphorylated $\mathrm{Rb}$ levels upon $\gamma$-irradiation. Similarly, ectopic expression of Pin1 resulted in $\mathrm{Rb}$ hyperphosphorylation in S-phase, albeit less than in cells expressing SV40 st (Figure 5c). Taken together, these data suggest that Pin1, like SV40 st, can sustain Rb phosphorylation via the inhibition of PP2A in response to S-phase DNA damage.

As it has been shown that $\mathrm{Rb}$ remains hyperphosphorylated throughout the cell cycle until late M-phase, ${ }^{15,16}$ we investigated whether Pin1 affected $\mathrm{Rb}$ dephosphorylation at M-phase. H1299 cells stably expressing GFP, st or Pin1 were synchronized with nocodazole and then released. As expected, $\mathrm{Rb}$ was rapidly dephosphorylated upon release from nocodazole in control cells (Figures $5 d$ and e), whereas SV40 st dramatically inhibited dephosphorylation. Similarly, Pin1 expression delayed $\mathrm{Rb}$ dephosphorylation (Figures $5 \mathrm{~d}$ and e). Thus, these data suggest that Pin1 has a role in the regulation of $\mathrm{Rb}$ phosphorylation at mitotic exit.

Pin1 has a role at S-phase checkpoint. As $\mathrm{Rb}$ has a critical role in S-phase checkpoint control upon DNA damage, and 
a

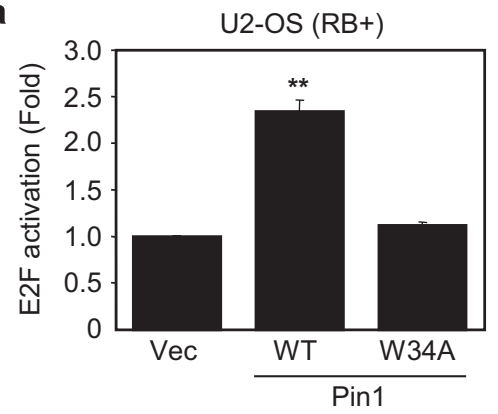

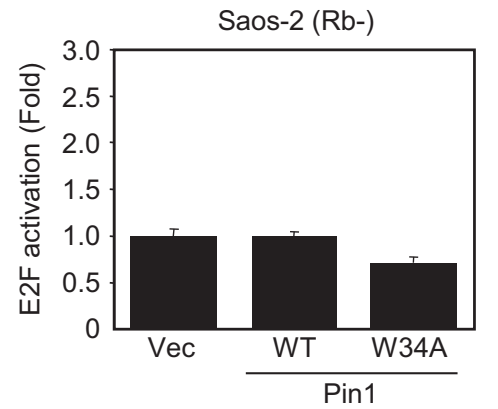

b

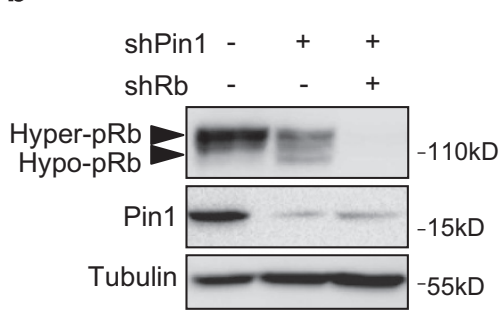

c

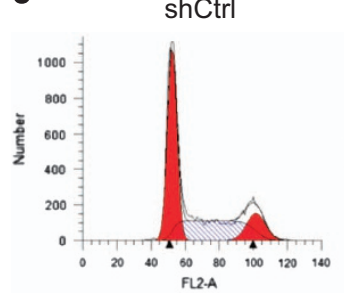

G1: $49.95 \%$

S: $36.02 \%$

G2/M: $14.03 \%$

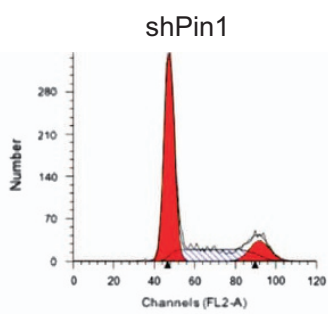

G1: $63.72 \%$

S: $24.15 \%$

G2/M: $12.13 \%$

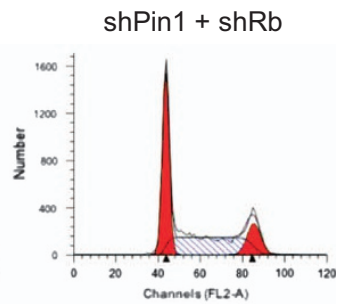

G1: $43.74 \%$

S: $41.39 \%$

G2/M: $14.87 \%$

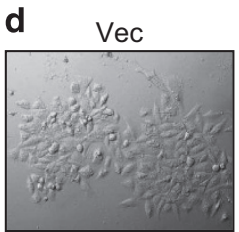

Pin1

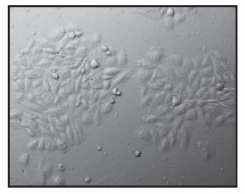

$\mathrm{Rb}+\operatorname{Pin} 1(\mathrm{~W} 34 \mathrm{~A})$

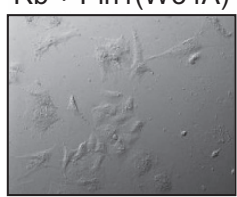

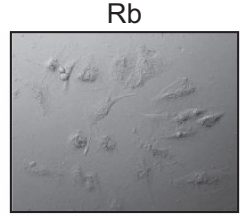

$\mathrm{Rb}+\mathrm{Pin} 1$
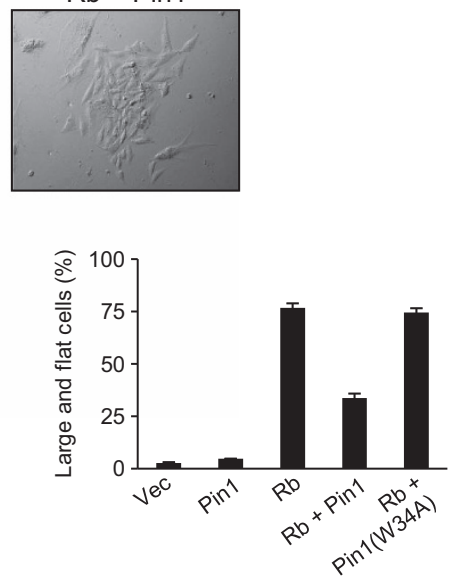

e $\quad \mathrm{Vec}$

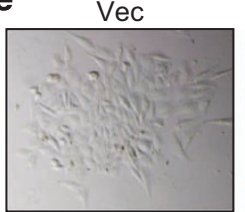

Pin1

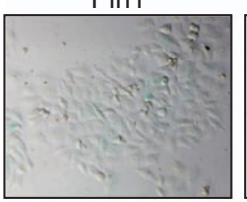

$\mathrm{Rb}+\operatorname{Pin} 1(\mathrm{~W} 34 \mathrm{~A})$

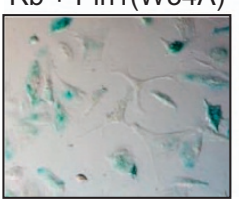

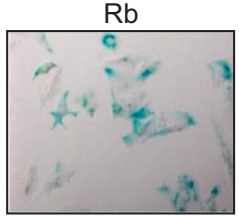

$\mathrm{Rb}+\operatorname{Pin} 1$
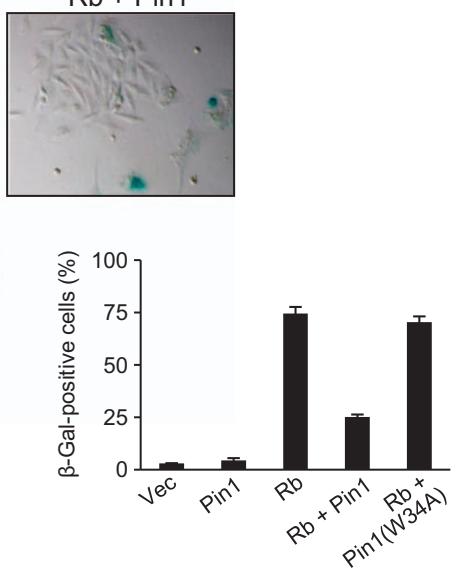

Figure 4 Pin1 inhibits Rb function in cell cycle progression and senescence. (a) U2-OS (Rb-positive) or Saos-2 (Rb-null) cells were co-transfected with WTor mutant Pin1, or a vector control, along with an E2F1-responsive DHFR-Luciferase (DHFR-Luc) reporter and a $\beta$-Galactosidase expression plasmid. Cells were lysed $24 \mathrm{~h}$ after transfection and subjected to luciferase and $\beta$-Galactosidase activity assays. DHFR-Luc activity was normalized to $\beta$-Galactosidase activity as described in the Materials and Methods and presented as fold activation. Results presented as means and S.E. of three independent experiments performed in triplicate. ${ }^{\star \star} P<0.01$. (b) $\mathrm{H} 1299$ cells were stably infected with shRNA against Rb, Pin1 or a control, and selected by puromycin resistance. Cell lysates were subjected to western blotting, as indicated. (c) Stable H1299 cells were subjected to flow cytometry for analysis of cell cycle stage. (d and e) Saos-2 cells were co-transfected with Rb and/or WT or mutant Pin1, or with a vector control, and selected by puromycin resistance, as described in the Materials and Methods. Stable cells were grown in normal growth media supplemented with $0.5 \mu \mathrm{g} / \mathrm{ml}$ puromycin for 10 days. Cells were then visualized under a light microscope for the analysis of large/flat phenotype (d) or were subjected to $\beta$-Galactosidase staining (e). Cells were scored and presented as the percentage of stained cells over total cells. Results are presented as representative images and mean and S.E. from three independent experiments. At least 300 cells were counted for each condition

our data indicate that Pin1 can regulate $\mathrm{Rb}$ activity via modulation of $\mathrm{Rb}$ phosphorylation, we investigated the role of Pin1 in checkpoint control upon DNA damage during S-phase. H1299 cells stably expressing Pin1, SV40 st or
GFP were synchronized at S-phase with HU, and subsequently released and then exposed to $20 \mathrm{~Gy} \gamma$-irradiation. Cells were then labeled with BrdU. $\gamma$-Irradiation led to marked inhibition of DNA synthesis in control cells, as expected, 

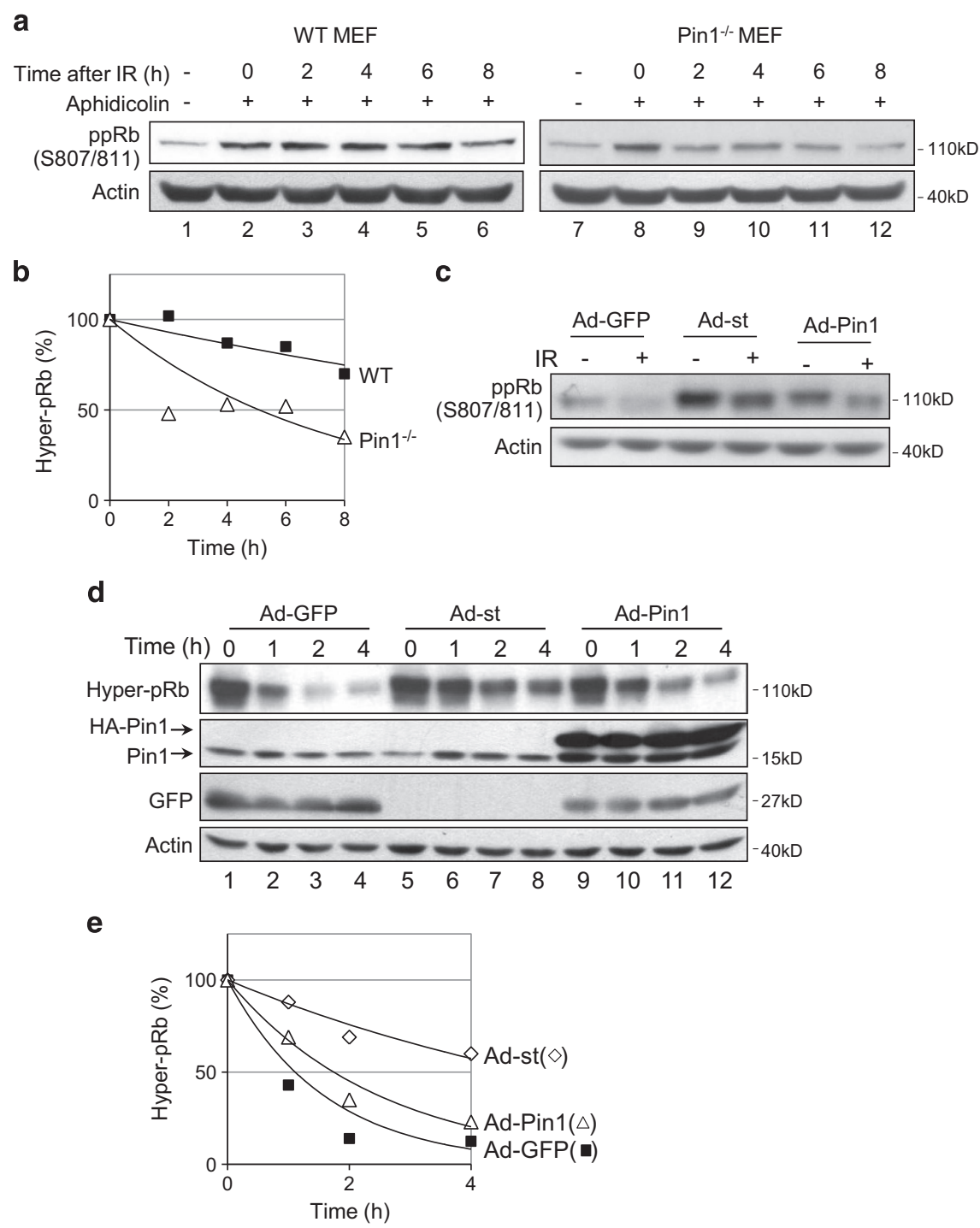

Figure 5 Pin1 modulates Rb dephosphorylation in cell cycle control. (a) WTor Pin $1^{-1-}$ MEF cells were synchronized with aphidicolin and then $\gamma$-irradiated (20 Gy). Samples were collected every $2 \mathrm{~h}$ for $8 \mathrm{~h}$ and subjected to western blotting, as shown. (b) Rb phosphorylation was quantitated by densitometry analysis and expressed as a percentage of Rb phosphorylation at time zero. (c) IMR90 cells were stably infected with adenovirus expressing GFP and HA-tagged Pin1 (Ad-Pin1), SV40 small t antigen alone (Ad-st), or GFP alone (Ad-GFP). Cells were synchronized with $1.0 \mathrm{mM}$ hydroxyurea for $18 \mathrm{~h}$, released and then $\gamma$-irradiated (20 Gy). Samples were collected $6 \mathrm{~h}$ post irradiation and subjected to western blotting, as shown. (d) H1299 cells were stably infected with Ad-GFP, Ad-st or Ad-Pin1. Six hours post infection, cells were synchronized with $100 \mathrm{ng} / \mathrm{ml}$ nocodazole for $18 \mathrm{~h}$. Mitotic cells were shaken off and grown in fresh media for the indicated times. Whole-cell lysates were subjected to western blotting as indicated. Rb phosphorylation was quantitated by densitometry analysis and expressed as a percentage of Rb phosphorylation at time zero. (e) Rb phosphorylation was quantitated by densitometry analysis, normalized to actin and expressed as a percentage of Rb phosphorylation at time zero

whereas the expression of either SV40 st or Pin1 resulted in higher levels of BrdU incorporation upon DNA damage (Figure 6a), suggesting that Pin1 can impede S-phase checkpoint in response to DNA damage.

Next we examined the effects of silencing Pin1 in IRinduced S-phase checkpoint using radioresistant DNA synthesis (RDS) assays. Stable cells expressing shRNA specific for Pin1 were first labeled with methyl- $\left[{ }^{14} \mathrm{C}\right]$-thymidine, synchronized at S-phase and released, and then subjected to $\gamma$-irradiation (5 or $10 \mathrm{~Gy}$ ), followed by pulse labeling with methyl- $\left[{ }^{3} \mathrm{H}\right]$-thymidine to determine the amount of ongoing DNA synthesis after DNA damage. Exposure to 5 and 10 Gy $\gamma$-irradiation led to $\sim 15$ and $20 \%$ reductions in $\left[{ }^{3} \mathrm{H}\right]$-thymidine incorporation, respectively. Notably, Pin1 ablation further reduced DNA synthesis upon DNA damage, resulting in over $30 \%$ reductions in $\left[{ }^{3} \mathrm{H}\right]$-thymidine incorporation. In addition, these effects were effectively reverted by reconstituting Pin1 expression (Figure 6b). These data indicate that Pin1 has an important role in IR-induced S-phase checkpoint.

To further examine the role of Pin1 in S-phase checkpoint control, we conducted RDS assays in Pin1-deficient and WT MEFs. Although $\gamma$-irradiation of WT MEF cells led to a dosedependent decrease in DNA synthesis, Pin1 deficiency led to further reduced DNA synthesis (Figure 6c). Next we reintroduced either WT Pin1, Rb binding-deficient Pin1(W34A), or Pin1(R68,69A) defective in isomerase activity, ${ }^{36}$ into Pin $1^{-1-}$ 
a
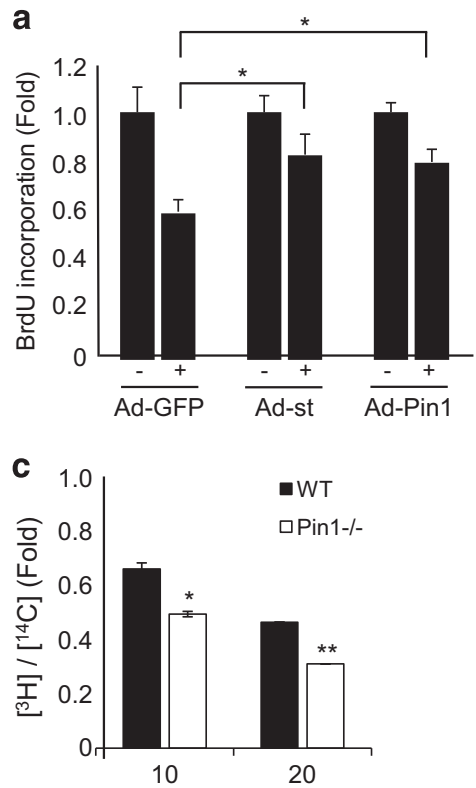

b

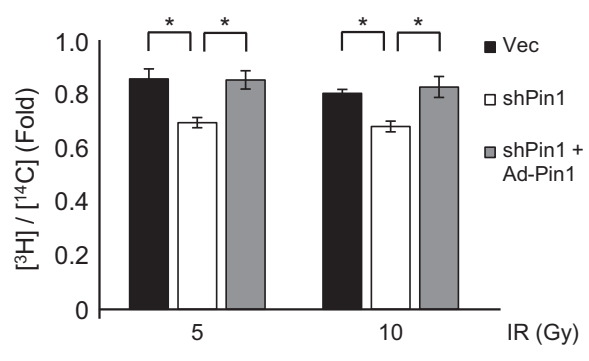

d

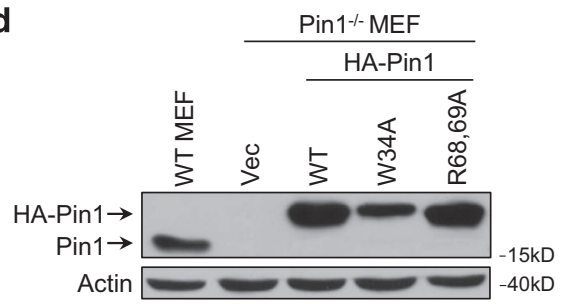

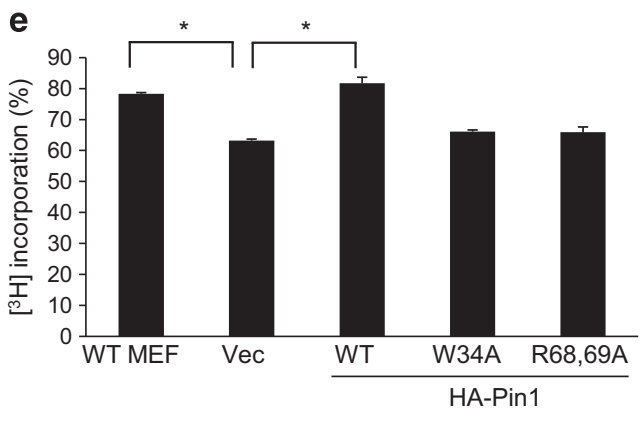

Pin 1 - MEF

Figure 6 Pin1 has a critical role in S-phase checkpoint control. (a) H1299 cells were infected with adenovirus expressing GFP and HA-tagged Pin1 (Ad-Pin1), SV40 small t antigen alone (Ad-st) or GFP alone (Ad-GFP). Cells were synchronized with $1.0 \mathrm{mM} \mathrm{HU}$ for $18 \mathrm{~h}$ and then released, followed by $\gamma$-irradiation and labeled with 5-bromo-2'deoxyuridine (BrdU). Cells were then fixed, stained with anti-BrdU antibody, counterstained with DAPI and visualized by fluorescent microscopy. Results were normalized to untreated controls. At least 100 cells were scored for each condition. Results are expressed as means and S.E. from three independent experiments. ${ }^{*} P<0.05$. (b) H1299 cells were stably transfected with shRNA against Pin1 (shPin1) or a vector control (Vec), and with adenovirus encoding Pin1 (Ad-Pin1), as indicated. Stable cells were subjected to RDS assay as following: cells were prelabeled with $\left[{ }^{14} \mathrm{C}\right]$-thymidine to provide an internal control for DNA content, synchronized with $1.0 \mathrm{mM} \mathrm{HU}$ for $18 \mathrm{~h}$ and then released. $\mathrm{S}$-phase cells were exposed to graded doses of $\gamma$-irradiation and then pulse labeled with $\left[{ }^{3} \mathrm{H}\right]$-thymidine for $15 \mathrm{~min}$. Relative DNA synthesis was determined as the ratio of $\left.{ }^{3} \mathrm{H}\right]$ thymidine to $\left[{ }^{14} \mathrm{C}\right]$-thymidine incorporation and normalized to the corresponding nonirradiated control. (c) RDS assays were performed in WTor Pin $1^{-1-}$ MEF cells as described above. ${ }^{*} P<0.05$; ${ }^{* *} P<0.01$. (d and e) WT or Pin1 ${ }^{-1-}$ MEF cells were transfected with HA-tagged WT or mutant Pin1 (W34A or R68,69A), or with a vector control, as shown. (d) Protein expression was assessed by western blotting. (e) Cells were subjected to RDS assays as described above. Results presented as mean $\left[{ }^{3} \mathrm{H}\right]$-thymidine incorporation and S.E. from three independent experiments

MEFs. Expression of WT and mutant Pin1 was confirmed by western blotting (Figure 6d). Consistently, RDS assays showed that Pin1 deficiency led to reduced $\left[{ }^{3} \mathrm{H}\right]$-thymidine incorporation upon $\gamma$-irradiation, which was reverted by WT Pin1, but not by Pin1(W34A) or Pin1(R68/69A) (Figure 6e). These data suggest that both the ability of Pin 1 to bind $R b$ and its isomerization activity are essential for Pin1 function on S-phase checkpoint control.

Pin1 overexpression correlates with hyperphosphorylation of $\mathbf{R b}$ in human breast cancer. Pin1 is frequently overexpressed in a variety of human cancers, including breast cancers. ${ }^{37}$ As our results show that Pin1 inhibits $\mathrm{Rb}$ function by maintaining $\mathrm{Rb}$ hyperphosphorylation, we examined whether there is a clinical relevance. We performed immunohistochemical staining of human breast tumor biopsy samples and scored for Pin1 and $\mathrm{Rb}$ phosphorylation (pS807/811). As shown in Figure 7a, hyperphosphorylation of $\mathrm{Rb}$ on $\mathrm{S} 807 / \mathrm{S} 811$ was found in $42.9 \%$ of all samples (12 out of 28), whereas the overexpression of Pin1 was found in $\sim 35 \%$ of all samples (10 out of 28 ). Notably, almost all tumors containing higher levels of Pin1 (9 out of 10) exhibited markedly higher levels of hyperphosphorylated Rb (pS807/ 811 ), whereas tumors that expressed lower levels of Pin1 (15 out of 18) similarly exhibited lower levels of hyperphosphorylated $\mathrm{Rb}$. Statistical analysis showed a significant positive correlation between Pin1 expression and $\mathrm{Rb}$ hyperphosphorylation, as determined by a Spearman rank 
a

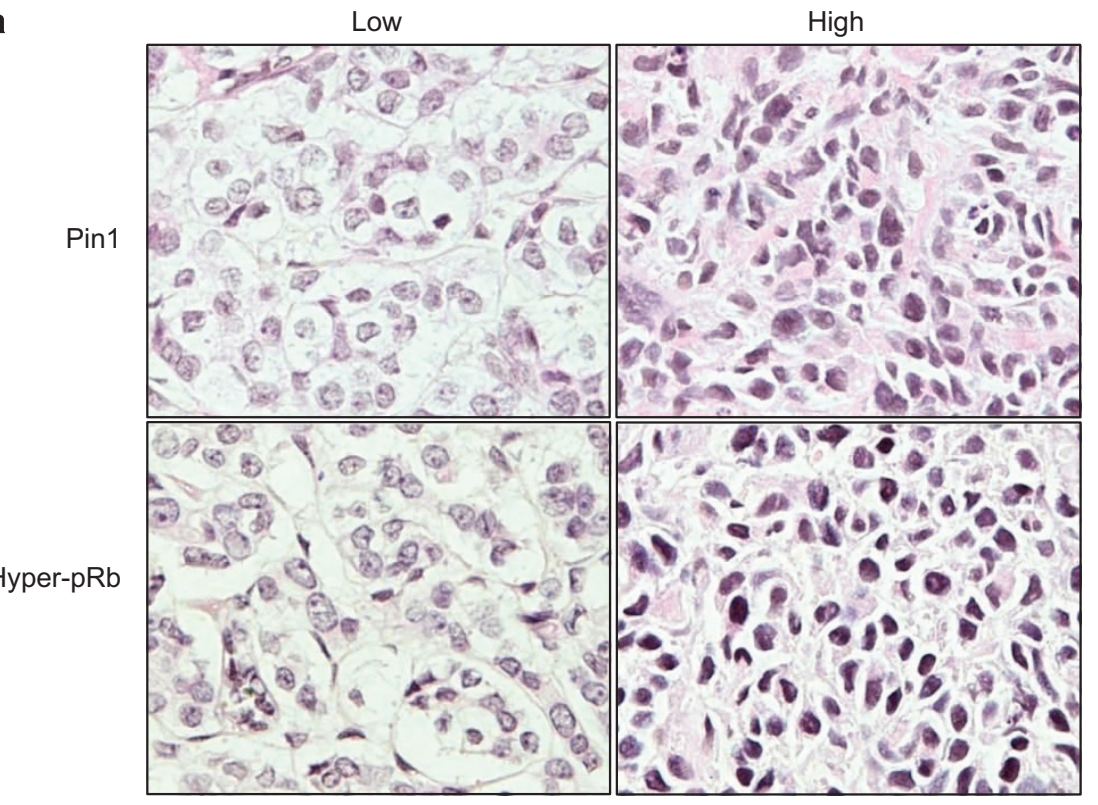

b

\begin{tabular}{|c|c|c|c|c|}
\hline & & \multicolumn{3}{|c|}{ Pin1 } \\
\hline & & Low & High & Total \\
\hline \multirow{3}{*}{$\mathrm{ppRb}$} & Low & $15(53.6 \%)$ & $\begin{array}{c}1 \\
(3.6 \%)\end{array}$ & $16(57.1 \%)$ \\
\hline & High & $\begin{array}{c}3 \\
(10.7 \%)\end{array}$ & $\begin{array}{c}9 \\
(32.1 \%)\end{array}$ & $12(42.9 \%)$ \\
\hline & Total & 18 (64.3\%) & $10(35.7 \%)$ & $28(100 \%)$ \\
\hline
\end{tabular}

Figure 7 Pin1 overexpression correlates with the hyperphosphorylation of $\mathrm{Rb}$ in human breast cancer. (a) Consecutive breast cancer sections were subjected to immunohistochemistry for Pin1 expression or hyperphosphorylated Rb (pS807/811) levels, and photographed under a light microscope. Micrographs were then analyzed and classified as high or low, depending on intensity of staining and percentage of positive cells. Representative images for each level are shown. (b) Summary of Pin1 expression and hyperphosphorylated $\mathrm{Rb}(\mathrm{pS} 807 / 811 ; \mathrm{ppRb})$ levels. Correlation was analyzed by the Spearman rank test $(P<0.001)$

correlation test $(P<0.001$; Figure $7 \mathrm{~b}$ and Supplementary Figure S1). Taken together, these results indicate that the overexpression of Pin1 is concomitant with Rb hyperphosphorylation in human breast cancer.

\section{Discussion}

The $\mathrm{Rb}$ protein is critically important for regulating cell cycle progression and DNA damage response. Hence, the tight regulation of $\mathrm{Rb}$ activity is crucial for preventing cellular transformation and tumorigenesis. We demonstrated here that Pin1 has an important role in Rb-mediated cell cycle regulation and S-phase checkpoint upon DNA damage. First, Pin1 specifically binds to the $\mathrm{RbC}$ and this interaction is dependent on Rb phosphorylation induced by G1/S cyclins. Second, Pin1 inhibits PP2A-mediated $\mathrm{Rb}$ dephosphorylation in vitro. Third, Pin1 expression effectively inhibits $\mathrm{Rb}$-induced premature cellular senescence. Fourth, the overexpression of Pin1 promotes $\mathrm{Rb}$ hyperphosphorylation and leads to defective S-phase check point upon DNA damage. Furthermore, Pin1 overexpression significantly correlates with $\mathrm{Rb}$ hyperphosphorylation in human breast cancer biopsy samples.

Multiple proteins have been shown to interact with hypophosphorylated $\mathrm{Rb}$, which is the biologically active species of $\mathrm{Rb}$. To date, except for protein phosphatases, there are no known cellular proteins that specifically interact with hyperphosphorylated Rb. Here we demonstrated that Pin1 specifically binds to $\mathrm{RbC}$ in a phosphorylation-dependent manner. Notably, the RbC contains multiple S/T-P moieties that are phosphorylated by Cyclin/CDK complexes and have a critical role in regulating $\mathrm{Rb}$ function. ${ }^{17,38}$ We found that mutation of these sites to alanine abolished Pin1-Rb interaction, whereas the expression of Cyclin A, Cyclin D1 or Cyclin E enhances Pin1-Rb binding. These observations are consistent with a recent report showing that CDK2 or CDK4/6 expression 
strengthens Rb-Pin1 interaction in glioblastoma multiforme cell lines. ${ }^{39}$ Of note, the authors also reported that the $\mathrm{Rb}$ small pocket, which excludes the $\mathrm{RbC}$, interacts with Pin1, as shown by GST pull-down assays in 293FT cells. ${ }^{39}$ The reasons for these discrepancies are unknown. Although these studies demonstrate that CDK-mediated Rb hyperphosphorylation is a prerequisite for Pin1-Rb interaction, the molecular mechanisms responsible for Pin1-mediated regulation of $\mathrm{Rb}$ function have not yet been elucidated. $\mathrm{Rb}$ function is determined by its phosphorylation status, which depends on the kinetics of phosphorylation by Cyclin/CDK complexes and dephosphorylation by phosphatases, such as PP1 and PP2A. Here we found that WT Pin1, but not Pin1 mutant derivatives defective in $\mathrm{Rb}$ binding, inhibit $\mathrm{Rb}$ function in cell cycle progression and in premature cellular senescence. Moreover, Pin1 prevents Rb dephosphorylation at S-phase checkpoint, thus preventing Rb-mediated cell cycle arrest. Our data indicate that Pin1 directly inhibits PP2A, therefore maintaining $\mathrm{Rb}$ hyperphosphorylation. Interestingly, PP2A normally dephosphorylates phospho-Ser/Thr-Pro isomers in the trans conformation, ${ }^{26,40}$ and Pin1-mediated cis-trans proline isomerization generally promotes PP2A-mediated dephosphorylation of a number of proteins, such as Pim-1 kinase, ${ }^{41}$ raf- $1,{ }^{30} \mathrm{C}-\mathrm{Myc},{ }^{31} \mathrm{Cdc}_{25 \mathrm{C}}{ }^{26}$ and Tau. ${ }^{26}$ Nevertheless, Pin1 has also been shown to inhibit PP2A-mediated dephosphorylation of neurofilament proteins in cortical neurons. ${ }^{42}$ Hence, the specific molecular mechanisms underlying inhibition of PP2A by Pin1 require further investigation. It is possible that specific conformational changes upon Pin1-mediated isomerization might mask docking sites for PP2A and, therefore, the outcome of Pin1 action for PP2A may vary depending on the substrates and signaling context.

Nonetheless, Pin1 may enhance Rb hyperphosphorylation by other mechanisms. For example, Pin1 has been reported to induce Cyclin D1 expression and enhance its function. ${ }^{27,37,43}$ Thus, it is possible that $\mathrm{Pin} 1$ modulates $\mathrm{Rb}$ phosphorylation by combined effects of Cyclin D1 activation and PP2A inhibition. However, Cyclin D proteins have a major role in mediating $R b$ phosphorylation during G1 phase, but less likely during S-phase. Interestingly, it was reported that S-phase DNA damage downregulates CDK2 and Cyclin D1.44,45 Thus, it could be that reduction of $\mathrm{Rb}$ phosphorylation upon S-phase DNA damage is a consequence of reduced Cyclin/CDK activity. However, DNA damage-induced accumulation of hypophosphorylated $\mathrm{Rb}$ during $\mathrm{S}$-phase does not require CDK inhibitors p16 ${ }^{\text {INK4A }}$ or p21 WAF1/CIP1 (ref. 21). Therefore, although a potential contribution by changes in CDK activity cannot be completely ruled out, it is likely that the observed $\mathrm{Rb}$ hypophosphorylation upon S-phase DNA damage results mainly from PP2A-induced dephosphorylation and that Pin1 inhibits this process by directly interacting with hyperphosphorylated $\mathrm{Rb}$.

In addition to having a role in S-phase DNA damage control, we showed that Pin1 inhibits Rb dephosphorylation at mitotic exit. It is conceivable that Pin1 is involved in temporal regulation of $\mathrm{Rb}$ dephosphorylation, and that abnormally high Pin1 levels may disrupt this process, leading to defects in cell cycle progression.

$\mathrm{Rb}$ dysregulation is directly linked to tumorigenesis and cancer progression. Germline mutations in the RB1 gene often result in childhood retinoblastoma. ${ }^{46}$ Similarly, $R B 1$ mutations have also been found in numerous human cancers, including small-cell lung carcinoma, osteosarcoma and melanoma. $^{47-49}$ Furthermore, aberrations leading to the abnormal activation of $\mathrm{Rb}$ kinases, such as cyclin D1 overexpression and inactivation of $\mathrm{p} 16^{\mathrm{INK} 4 \mathrm{~A}}$, are frequently found in human cancers. ${ }^{50}$ Similarly, Pin1 overexpression is often correlated with cancer progression. ${ }^{37,51}$ Moreover, Pin1 was shown to enhance tumorigenesis and metastasis induced by mutant p53 in mouse models. ${ }^{52}$ However, much less is known about the link between $\mathrm{Rb}$ dephosphorylation and tumorigenesis. Here we found that the overexpression of Pin1 correlates with increased $\mathrm{Rb}$ phosphorylation in breast cancer. We previously reported that Pin1 is overexpressed and closely correlated with $\mathrm{Rb}$ phosphorylation in DMBA-induced tumors in mice, compared with normal mammary glands. ${ }^{53}$ Also, Pin1 expression correlates with $\mathrm{Rb}$ phosphorylation in human glioma samples, ${ }^{54}$ suggesting that increased Pin1 expression could account, at least in part, for $\mathrm{Rb}$ inactivation. Notably, analyses of TCGA database ${ }^{55}$ reveals a clear correlation between Pin1 mRNA levels and phosphoralated Rb (S807/ $811)$ in Glioblastoma $(N=70, P<0.01)$. However, analysis of the TCGA database does not reveal a clear correlation in invasive breast adenocarcinoma ${ }^{56}$. The reasons for the discrepancy between this analysis and this study are not yet clear. It is possible that Pin1 mRNA levels do not reflect actual protein levels, as reported before ${ }^{57}$. Together this study suggests that Pin1 overexpression and subsequent sustaining of $\mathrm{Rb}$ hyperphosphorylation may have an important pathological role in cancer development.

\section{Materials and Methods}

Cell culture and synchronization. Human osteosarcoma Saos-2 and U2-OS cells and human non-small-cell lung carcinoma H1299 cells were maintained in Dulbecco's modified Eagle medium (DMEM; Invitrogen Inc., Carlsbad, CA, USA) containing $4.5 \mathrm{~g} / \mathrm{l}$ glucose supplemented with either $10 \%$ newborn calf serum (NCS; U2-OS) or 10\% fetal bovine serum (FBS; Saos-2) or $5 \%$ FBS (H1299). Human nontransformed mammary epithelial MCF-10A cells were maintained in $1: 1$ mixture of DMEM and Ham,s F12 medium with reduced $\mathrm{Ca}^{2+}$ $(0.04 \mathrm{mM}$; Invitrogen Inc.), $20 \mathrm{ng} / \mathrm{ml}$ epidermal growth factor (Invitrogen Inc.), $100 \mathrm{ng} / \mathrm{ml}$ cholera toxin (Sigma, St. Louis, MO, USA), $10 \mu \mathrm{g} / \mathrm{ml}$ insulin (Sigma), $500 \mathrm{ng} / \mathrm{ml}(95 \%)$ hydrocortisone (Sigma) and $5 \%$ of Chelex-treated horse serum (Invitrogen Inc.). Primary human lung fibroblast IMR90 cells were maintained in DMEM supplemented with 10\% FBS and $0.1 \mathrm{mM}$ nonessential amino acids (GIBCO Life Technologies, Rockville, MD, USA). WT and Pin1-null MEFs were maintained in DMEM supplemented with $10 \%$ FBS. For synchronization studies, cells were grown to $60 \%$ confluence and treated with $1.0 \mathrm{mM} \mathrm{HU}$ for $18 \mathrm{~h}$ or $2.0 \mu \mathrm{g} / \mathrm{ml}$ aphidicolin for $24 \mathrm{~h}$ or $100 \mathrm{ng} / \mathrm{ml}$ nocodazole for $18 \mathrm{~h}$. Cells were released by washing twice with phosphate-buffered saline (PBS) and once with growth media, and then incubated in normal growth media.

Plasmid transfections, viral infection and RNA interference. Transient transfections were carried out using FuGENE 6 (Roche, Indianapolis, IN, USA) for U2-OS cells, Lipofectamine 2000 (Invitrogen Inc.) for H1299, MEF and Saos-2 cells (where indicated) or CalPhos mammalian transfection kit (Clontech, Mountain View, CA, USA) for Saos-2 cells, according to manufacturer's instructions. Transient expression plasmids include $\mathrm{pCMV}-\mathrm{Rb}$ (full length, and deletion or point mutant), HA-tagged pHook2-Pin1 (WT and point mutant), PLVXpuro-Pin1 (WT or point mutant) and adenoviral expression plasmids include Pin1-pAdTrack-CMV, SV40 small $t$ antigen (st)-pAdTrack-CMV, and GFP-pAdTrack-CMV. These plasmids were described previously. ${ }^{11,25}$ Short hairpin RNA against Pin1 (5'-AGGCCGAGTGTACTACTTCAA-3') was cloned into a pSM2 retroviral vector (Thermo Fisher Scientific, Waltham, MA, USA). Retrovirus and adenovirus were amplified by transfecting 293FT cells with the corresponding backbone, and 
packaging plasmids; supernatants were collected after $48 \mathrm{~h}$, filtered, and either used immediately or stored at $-80^{\circ} \mathrm{C}$. Retrovirus were concentrated by ultracentrifugation at 27000 r.p.m. for $90 \mathrm{~min}$ at $4^{\circ} \mathrm{C}$. For viral transductions, cells at $60 \%$ confluency were incubated with retrovirus (viral titers of $10^{8}$ to $10^{9} \mathrm{CFU} / \mathrm{ml}$ ) or adenovirus (MOI of $1: 100$ ) for $90 \mathrm{~min}$ at $37^{\circ} \mathrm{C}$ with mild agitation at 20-min intervals, followed by the addition of culture media supplemented with $10 \mu \mathrm{g} / \mathrm{ml}$ polybrene and incubation for $24 \mathrm{~h}$.

Luciferase activity assays. U2-OS or Saos-2 cells in six-well plates were co-transfected with $1.5 \mu \mathrm{g}$ (U2-OS) or $4.0 \mu \mathrm{g}$ (Saos-2) WT or mutant HA-tagged pHook2-Pin1, along with $0.5 \mu \mathrm{g}$ (U2-OS) or $2.0 \mu \mathrm{g}$ (Saos-2) DHFR-Luciferase, and $100 \mathrm{ng}$ (U2-OS) or $400 \mathrm{ng}$ (Saos-2) pCMV- $\beta$-Galactosidase plasmids, and harvested $24 \mathrm{~h}$ after transfection. Luciferase activity was measured using a Luciferase Assay System kit (Promega, Madison, WI, USA) according to the manufacturer's instructions, and normalized to $\beta$-Galactosidase activity. For $\beta$-Galactosidase activity, $30 \mu \mathrm{l}$ cell lysates were incubated in $500 \mu \mathrm{l}$ LacZ buffer $\left(60 \mathrm{mM} \mathrm{Na}_{2} \mathrm{PO}_{4}, 40 \mathrm{mM} \mathrm{NaH}_{2} \mathrm{PO}_{4}, 10 \mathrm{mM} \mathrm{KCl}\right.$ and $\left.1.0 \mathrm{mM} \mathrm{MgSO}_{4}, \mathrm{pH} 6.95\right)$ and $100 \mu \mathrm{l}$ substrate solution $(2 \mathrm{mg} / \mathrm{ml}$ O-Nitrophenyl $\beta$-D-Galactopyranoside in $60 \mathrm{mM}$ $\mathrm{Na}_{2} \mathrm{HPO}_{4}$ and $40 \mathrm{mM} \mathrm{NaH}_{2} \mathrm{PO}_{4}$ ) at $37^{\circ} \mathrm{C}$ for $20 \mathrm{~min}$. The reaction was stopped by adding $250 \mu \mathrm{l} 1.0 \mathrm{M} \mathrm{Na}_{2} \mathrm{CO}_{3}$ and absorbance was measured at $420 \mathrm{~nm}$.

Western blot analyses, immunoprecipitation and immunofluorescence experiments. Unless indicated, cells were lysed in $\mathrm{EBC}_{250}$ lysis buffer $(250 \mathrm{mM} \mathrm{NaCl}, 50 \mathrm{mM}$ Tris. $\mathrm{HCl}, \mathrm{pH}$ 8.0, 0.5\% Nonidet P-40, $0.2 \mathrm{mM}$ PMSF, $2 \mu \mathrm{g} / \mathrm{ml}$ aprotinin and $2 \mu \mathrm{g} / \mathrm{ml}$ leupeptin, $5 \mathrm{mM} \mathrm{NaF}$ and $0.5 \mathrm{mM} \mathrm{NaVO}_{4}$ ), sonicated briefly and then centrifuged at $14000 \times g$ for $15 \mathrm{~min}$ at $4^{\circ} \mathrm{C}$. Supernatants were collected and protein concentrations were determined by Bio-Rad protein assay reagent (Bio-Rad, Hercules, CA, USA). For western blotting, samples were separated by SDS-PAGE, transferred to polyvinylidene difluoride membranes (NEN Life Sciences, Waltham, MA, USA), and hybridized to an appropriate primary antibody and horseradish peroxidase-conjugated secondary antibody for detection by enhanced chemiluminescence (Thermo Fisher Scientific Inc., Rockford, IL, USA). For immunoprecipitation, $\mathrm{H} 1299$ cells were lysed in $0.25 \%$ NP-40 buffer $(20 \mathrm{mM}$ Tris- $\mathrm{HCl}, \mathrm{pH} 7.8,125 \mathrm{mM} \mathrm{NaCl}, 0.25 \%$ Nonidet P-40, $0.2 \mathrm{mM}$ EDTA, $5 \mathrm{mM} \mathrm{MgCL2}$, $1 \mathrm{mM}$ PMSF, $5 \mathrm{mM} \mathrm{NaF}, 2 \mathrm{mM}$ Na3VO4), $2.0 \mathrm{mg} / \mathrm{ml}$ total protein were incubated with anti-FLAG M2 Affinity Gel (A2220, Sigma) for $8 \mathrm{~h}$. For immunoprecipitation in U2-OS cells, $2.0 \mathrm{mg} / \mathrm{ml}$ total protein was first precleared with normal mouse or rabbit lgG (Santa Cruz Biotechnology, Santa Cruz, CA, USA) for $1 \mathrm{~h}$, followed by the addition of agarose-conjugated Protein A/G beads (Santa Cruz Biotechnology) and incubated for 30 min with mild agitation. Supernatants were then incubated with a specific primary antibody or a control lgG for $2 \mathrm{~h}$, followed by the addition of agarose-conjugated protein A/G beads (Santa Cruz Biotechnology) and incubated for $1 \mathrm{~h}$. Immune complexes were then washed three times with lysis buffer and resolved by SDS-PAGE and western blotting. All incubations were performed at $4{ }^{\circ} \mathrm{C}$. Antibodies used for western blotting include Pan-Rb (G3-245, BD Biosciences, San Jose, CA, USA; and a mixture of monoclonal antibodies XZ77 and XZ91), hypophosphorylated Rb (G99-549; BD Biosciences), phosphorylated Ser780 (pS780), pS795 or pS807/811 Rb (\#9307, \#9301 and \#9308, respectively; Cell Signaling, Danvers, MA, USA), Pin1 (Ab-1, Oncogene Research Products, Cambridge, MA, USA; H123, sc-15340, Santa Cruz Biotechnology), and Actin (C-11, Santa Cruz Biotechnology). For immunofluorescence, cells were fixed with $4 \%$ paraformaldehyde, immunostained with primary $\mathrm{Rb}$ antibody and secondary Alexa Fluor 488 (A11001; Santa Cruz Biotechnology) antibodies in 4\% BSA, and counterstained with 4,6-diamidino-2-phenylindole (DAPI). For analysis of $\mathrm{Rb}$ association with nuclear matrix, cells were treated with or without extraction buffer $(250 \mathrm{mM} \mathrm{NaCl}, 10 \mathrm{mM}$ HEPES-KOH, pH 7.9, $0.1 \%$ Triton X-100, $0.5 \mathrm{mM}$ dithiothreitol, $0.2 \mathrm{mM}$ PMSF, $2 \mu \mathrm{g} / \mathrm{ml}$ aprotinin and $2 \mu \mathrm{g} / \mathrm{ml}$ leupeptin, $5 \mathrm{mM} \mathrm{NaF}$ and $0.5 \mathrm{mM} \mathrm{NaVO}_{4}$ ) before immunofluorescence. Cell images were recorded with an Axiovert $200 \mathrm{M}$ microscope (Carl Zeiss, Oberkochen, Germany) and analyzed with Axiovision 3.1 software (Carl Zeiss).

GST pull-down assays. GST pull-down assays were performed essentially as previously described. ${ }^{58}$ In brief, cells were lysed in $\mathrm{EBC}_{200}$ buffer (same as $\mathrm{EBC}_{250}$, but containing $200 \mathrm{mM} \mathrm{NaCl}$ ) supplemented with $10 \%$ (v/v) glycerol. Equal amounts of proteins were incubated with $20 \mu$ l Glutathione-Sepharose 4B Beads loaded with various GST-Pin1 proteins or the control GST for $3 \mathrm{~h}$ at $4{ }^{\circ} \mathrm{C}$. Beads were then washed with $\mathrm{EBC}_{200}$ buffer and subjected to western blot analyses.
In vitro phosphorylation and dephosphorylation. First, $400 \mathrm{ng}$ of $\mathrm{RbC}$ protein (Cell Signaling, \#6022) were labeled by in vitro phosphorylation in a reaction system containing $40 \mathrm{ng}$ Cyclin E/CDK2 (Cell Signaling, \#7524), $30 \mu \mathrm{Ci}$ $\gamma-\left[{ }^{32} \mathrm{P}\right]$-ATP (NEN Life Sciences), $100 \mu \mathrm{M}$ ATP, $50 \mathrm{mM}$ Tris- $\mathrm{HCl} \mathrm{pH} \mathrm{7.5,} 10 \mathrm{mM}$ $\mathrm{MgCl}_{2}, 1 \mathrm{mM}$ EGTA, $2 \mathrm{mM}$ DTT and $0.01 \%$ (w/v) Brij-35 by incubation at $30^{\circ} \mathrm{C}$ for $30 \mathrm{~min}$. The reaction was stopped by increasing the temperature to $65^{\circ} \mathrm{C}$ for $10 \mathrm{~min}$. Free $\gamma-\left[{ }^{32} \mathrm{P}\right]-$ ATP was removed by centrifugation through three SephadexG25 columns (Roche) at 3200 r.p.m. for $10 \mathrm{~min}$. Second, to determine the effect of Pin1 on $\mathrm{Rb}$ dephosphorylation in vitro, $200 \mathrm{ng}$ of in vitro phosphorylated $\mathrm{RbC}$ protein were incubated with either BSA $(0.04 \mu \mathrm{g} / \mu \mathrm{l}), 10 \mathrm{nM}$ okadaic acid, or purified GST-Pin1 protein $(0.04 \mu \mathrm{g} / \mu \mathrm{l})$ in $50 \mu \mathrm{l}$ dephosphorylation buffer $(10 \%$ Glycerol, $20 \mathrm{mM}$ MOPS pH 7.4, $0.1 \mathrm{M} \mathrm{NaCl}, 1 \mathrm{mM} \mathrm{MgCl}, 0.1 \mathrm{mM} \mathrm{MnCl}_{2}, 60 \mathrm{mM}$ $\beta$-mercaptomethanol, $1 \mathrm{mM} \mathrm{EGTA}, 1 \mathrm{mM}$ DTT and $0.1 \mu \mathrm{g} / \mu \mathrm{l} \mathrm{BSA}$ ) at $30^{\circ} \mathrm{C}$ for $15 \mathrm{~min}$. Then, $5.0 \mathrm{ng}$ purified PP2A (Upstate Biotechnology, Lake Placid, NY, USA) were added to the reaction mixture, bringing the final volume to $100 \mu \mathrm{l}$ and incubated at room temperature. Aliquots were removed every $10 \mathrm{~min}$ and subsequently resolved by SDS-PAGE. [ $\left.{ }^{32} \mathrm{P}\right]$-labeled $\mathrm{RbC}$ was detected by autoradiography.

Flow cytometry. Cells were first incubated in Buffer A ( $4.0 \mathrm{mM}$ Sodium citrate $\mathrm{pH} 7.8,0.1 \%$ Triton-X-100, $100 \mu \mathrm{g} / \mathrm{ml}$ RNase A and $50 \mu \mathrm{g} / \mathrm{ml}$ propidium iodide) at room temperature for $10 \mathrm{~min}$. An equal volume of Buffer B $(400 \mathrm{mM} \mathrm{NaCl}, 0.1 \%$ Triton-X-100, $50 \mu \mathrm{g} / \mathrm{ml} \mathrm{PI}$ ) was added and incubated overnight at $4{ }^{\circ} \mathrm{C}$. Cells were then subjected to flow cytometry analysis by FACScan Flow Cytometer (Becton Dickinson Biosciences, Franklin Lakes, NJ, USA), and the data were analyzed using Cell Quest software (Becton Dickinson Biosciences).

RDS assay. For RDS assays, cells were incubated with methyl- $\left[{ }^{14} \mathrm{C}\right]$-thymidine (10 nCi/ml) (NEN Life Sciences) for $24 \mathrm{~h}$ for labeling. Cells were then synchronized as described above, and subjected to graded doses of $\gamma$-irradiation. After $45 \mathrm{~min}$, cells were pulse labeled with $2.0 \mu \mathrm{Ci} / \mathrm{ml}$ methyl $\left[{ }^{3} \mathrm{H}\right]$-thymidine (NEN Life Sciences) for $15 \mathrm{~min}$. Cells were washed once with ice-cold PBS and three times with $5 \%$ trichloroacetic acid and then air dried at room temperature overnight and harvested. Radioactivity was measured in a liquid scintillation counter, and DNA synthesis was represented as the ratio of $\left[{ }^{3} \mathrm{H}\right]$ counts over $\left[{ }^{14} \mathrm{C}\right]$ counts and normalized to the corresponding control.

BrdU incorporation assay. Cells were labeled with $10 \mu \mathrm{M}$ BrdU (Roche) for $3 \mathrm{~h}$, fixed with $70 \%$ ethanol supplemented with $15 \mathrm{mM}$ glycine $\mathrm{pH} 2.0$ for $30 \mathrm{~min}$ at $-20^{\circ} \mathrm{C}$, and immunostained with anti-BrdU antibody (Roche) followed by staining with Cy3-conjugated goat anti-mouse IgG (Jackson ImmunoResearch Laboratories, West Grove, PA, USA; 115-165-146) and counterstained with DAPI. BrdU-positive cells were scored under a fluorescent microscope. Three different fields were analyzed, and at least 100 nuclei were counted per field. Results were normalized to untreated controls.

Assays for senescence-associated phenotypes. For $\mathrm{Rb}$ growth suppression assays, Saos-2 cells were co-transfected with pCMV-Rb and/or PLVX-Pin1 (WT or mutant) by Lipofectamine 2000 (Invitrogen Inc.) and selected by puromycin resistance $(0.5 \mu \mathrm{g} / \mathrm{ml})$. Stable cells were grown in normal growth media for 10 days. Cells were then visualized under a light microscope and assessed for percentage of large, flat cell morphology. For senescenceassociated $\beta$-Galactosidase (SA- $\beta$-Gal) staining, cells were fixed with $3.7 \%$ formaldehyde in PBS for 15 min at room temperature, washed and stained with $\mathrm{X}$-Gal solution (Beyotime, Shanghai, China) for $16 \mathrm{~h}$ at $37^{\circ} \mathrm{C}$. Cells were then visualized under a light microscope and assessed for percentage of $\beta$-Gal-positive cells.

Immunohistochemistry analyses. Paraffin-embedded tissue sections of human breast cancer biopsy samples were purchased from West China Hospital of Sichuan University (Chengdu, Sichuan, China). For immunohistochemistry, slides were dewaxed in xylene, rehydrated in ethanol and then pretreated with $1 \% \mathrm{H}_{2} \mathrm{O}_{2} /$ $10 \%$ methanol in PBS for $15 \mathrm{~min}$ at room temperature to quench endogenous peroxidase activity. Sections were blocked with $2 \% \mathrm{BSA}$ for $1 \mathrm{~h}$ at room temperature, followed by incubation with anti-Pin1 (H123; Santa Cruz Biotechnology) or anti-pS807/811-Rb (\#9308; Cell Signaling) overnight. After extensive washing, the slides were incubated with biotinylated horse anti-rabbit IgG (BA-1000; Vector Laboratories, Burlingame, CA, USA). Reaction products were visualized with the $A B C$ Elite kit (Vector Laboratories) according to manufacturer's instructions. 
Slides were then counterstained with hematoxylin and eosin (Sigma). Double-blind scoring was then performed for Pin1 and Rb according to intensity of staining and percentage of positive cells. Statistical analysis was performed by Spearman correlation rank test.

\section{Conflict of Interest}

The authors declare no conflict of interest.

Acknowledgements. We thank Dr Takafumi Uchida (Tohoku University, Japan) for kindly providing WT and Pin1-null MEFs and Dr Nicklos Dyson (Massachusetts General Hospital, Harvard Medical School, Boston, MA, USA) for kindly providing monoclonal antibodies XZ77 and XZ91 against Pan-Rb. This work was supported by the National Key Basic Research Program (973 Program) of China (2012CB910700) and National Natural Science Foundation of China (NSFC) grant (31171362 and 81330054) and NIH grant (CA79804) to Z-XX and NSFC grant (31350110216) to JB.

1. Harbour JW, Dean $\mathrm{DC}$. The Rb/E2F pathway: expanding roles and emerging paradigms. Genes Dev 2000; 14: 2393-2409.

2. Lipinski MM, Jacks T. The retinoblastoma gene family in differentiation and development. Oncogene 1999; 18: 7873-7882.

3. Stevaux O, Dyson NJ. A revised picture of the E2F transcriptional network and RB function. Curr Opin Cell Biol 2002; 14: 684-691.

4. Burkhart DL, Sage J. Cellular mechanisms of tumour suppression by the retinoblastoma gene. Nat Rev Cancer 2008; 8: 671-682.

5. Korenjak M, Brehm A. E2F-Rb complexes regulating transcription of genes important for differentiation and development. Curr Opin Genet Dev 2005; 15: 520-527.

6. Isaac CE, Francis SM, Martens AL, Julian LM, Seifried LA, Erdmann $N$ et al. The retinoblastoma protein regulates pericentric heterochromatin. Mol Cell Biol 2006; 26: 3659-3671.

7. Lee JO, Russo AA, Pavletich NP. Structure of the retinoblastoma tumour-suppressor pocket domain bound to a peptide from HPV E7. Nature 1998; 391: 859-865.

8. Hiebert SW. Regions of the retinoblastoma gene product required for its interaction with the E2F transcription factor are necessary for E2 promoter repression and pRb-mediated growth suppression. Mol Cell Biol 1993; 13: 3384-3391.

9. Qin $X Q$, Chittenden T, Livingston DM, Kaelin WG. Identification of a growth suppression domain within the retinoblastoma gene product. Genes Dev 1992; 6: 953-964.

10. Julian LM, Palander O, Seifried LA, Foster JEG, Dick FA. Characterization of an E2F1specific binding domain in pRB and its implications for apoptotic regulation. Oncogene 2008; 27: 1572-1579.

11. Sdek $\mathrm{P}$, Ying H, Chang DLF, Qiu W, Zheng H, Touitou R et al. MDM2 promotes proteasomedependent ubiquitin-independent degradation of retinoblastoma protein. Mol Cell 2005; 20: 699-708.

12. Sdek $\mathrm{P}$, Ying $\mathrm{H}$, Zheng $\mathrm{H}$, Margulis $\mathrm{A}$, Tang $\mathrm{X}$, Tian $\mathrm{K}$ et al. The central acidic domain of MDM2 is critical in inhibition of retinoblastoma-mediated suppression of E2F and cell growth. J Biol Chem 2004; 279: 53317-53322.

13. Giacinti C, Giordano A. RB and cell cycle progression. Oncogene 2006; 25: 5220-5227.

14. DeCaprio JA, Furukawa Y, Ajchenbaum F, Griffin JD, Livingston DM. The retinoblastomasusceptibility gene product becomes phosphorylated in multiple stages during cell cycle entry and progression. Proc Natl Acad Sci USA 1992; 89: 1795-1798.

15. Ludlow JW, Shon J, Pipas JM, Livingston DM, DeCaprio JA. The retinoblastoma susceptibility gene product undergoes cell cycle-dependent dephosphorylation and binding to and release from SV40 large T. Cell 1990; 60: 387-396.

16. Mittnacht S. Control of pRB phosphorylation. Curr Opin Genet Dev 1998; 8: 21-27.

17. Zarkowska T, Mittnacht S. Differential phosphorylation of the retinoblastoma protein by G1/S cyclin-dependent kinases. J Biol Chem 1997; 272: 12738-12746.

18. Ludlow JW, Glendening CL, Livingston DM, DeCarprio JA. Specific enzymatic dephosphorylation of the retinoblastoma protein. Mol Cell Biol 1993; 13: 367-372.

19. Avni D, Yang H, Martelli F, Hofmann F, ElShamy WM, Ganesan S et al. Active localization of the retinoblastoma protein in chromatin and its response to S phase DNA damage. Mol Cell 2003; 12: 735-746.

20. Cicchilliti L, Fasanaro P, Biglioli P, Capogrossi MC, Martelli F. Oxidative stress induces protein phosphatase 2A-dependent dephosphorylation of the pocket proteins pRb, p107, and p130. J Biol Chem 2003; 278: 19509-19517.

21. Knudsen KE, Booth D, Naderi S, Sever-Chroneos Z, Fribourg AF, Hunton IC et al. RB-dependent S-phase response to DNA damage. Mol Cell Biol 2000; 20: 7751-7763.

22. Bosco EE, Mayhew CN, Hennigan RF, Sage J, Jacks T, Knudsen ES. RB signaling prevents replication-dependent DNA double-strand breaks following genotoxic insult. Nucleic Acids Res 2004; 32: 25-34.

23. Lu KP, Zhou XZ. The prolyl isomer ase PIN1: a pivotal new twist in phosphorylation signalling and disease. Nat Rev Mol Cell Biol 2007; 8: 904-916.
24. Wulf G, Finn G, Suizu F, Lu KP. Phosphorylation-specific prolyl isomerization: is there an underlying theme? Nat Cell Biol 2005; 7: 435-441.

25. Zheng H, You H, Zhou XZ, Murray SA, Uchida T, Wulf G et al. The prolyl isomerase Pin1 is a regulator of p53 in genotoxic response. Nature 2002; 419: 849-853.

26. Zhou XZ, Kops 0 , Werner A, Lu PJ, Shen M, Stoller G et al. Pin1-dependent prolyl isomerization regulates dephosphorylation of $\mathrm{Cdc25C}$ and tau proteins. Mol Cell 2000; 6: 873-883.

27. Ryo A, Nakamura M, Wulf G, Liou YC, Lu KP. Pin1 regulates turnover and subcellular localization of beta-catenin by inhibiting its interaction with APC. Nat Cell Biol 2001; 3 : 793-801.

28. Verdecia MA, Bowman ME, Lu KP, Hunter T, Noel JP. Structural basis for phosphoserine-proline recognition by group IV WW domains. Nat Struct Biol 2000; 7: 639-643.

29. Mittnacht $S$, Weinberg RA. G1/S phosphorylation of the retinoblastoma protein is associated with an altered affinity for the nuclear compartment. Cell 1991; 65 381-393.

30. Dougherty MK, Müller J, Ritt DA, Zhou M, Zhou XZ, Copeland TD et al. Regulation of Raf-1 by direct feedback phosphorylation. Mol Cell 2005; 17: 215-224.

31. Yeh $E$, Cunningham M, Arnold $H$, Chasse $D$, Monteith $T$, Ivaldi $G$ et al. A signalling pathway controlling c-Myc degradation that impacts oncogenic transformation of human cells. Nat Cell Biol 2004; 6: 308-318.

32. Cohen P, Holmes CF, Tsukitani Y. Okadaic acid: a new probe for the study of cellular regulation. Trends Biochem Sci 1990; 15: 98-102.

33. Serrano M, Lin AW, McCurrach ME, Beach D, Lowe SW. Oncogenic ras provokes premature cell senescence associated with accumulation of p53 and p16INK4a. Cell 1997; 88: 593-602.

34. Skoczylas C, Fahrbach KM, Rundell K. Cellular targets of the SV40 small-t antigen in human cell transformation. Cell Cycle 2004; 3: 606-610.

35. Garriga J, Jayaraman AL, Limón A, Jayadeva G, Sotillo E, Truongcao M et al. A dynamic equilibrium between CDKs and PP2A modulates phosphorylation of pRB, p107 and p130. Cell Cycle 2004; 3 : 1320-1330.

36. Shen M, Stukenberg PT, Kirschner MW, Lu KP. The essential mitotic peptidyl-prolyl isomerase Pin1 binds and regulates mitosis-specific phosphoproteins. Genes Dev 1998; 12: 706-720.

37. Wulf GM, Ryo A, Wulf GG, Lee SW, Niu T, Petkova V et al. Pin1 is overexpressed in breast cancer and cooperates with Ras signaling in increasing the transcriptional activity of c-Jun towards cyclin D1. EMBO J 2001; 20: 3459-3472.

38. Kaelin WG. Functions of the retinoblastoma protein. Bioessays 1999; 21: 950-958.

39. Rizzolio F, Lucchetti C, Caligiuri I, Marchesi I, Caputo M, Klein-Szanto AJ et al. Retinoblastoma tumor-suppressor protein phosphorylation and inactivation depend on direct interaction with Pin1. Cell Death Differ 2012; 19: 1152-1161.

40. Brown NR, Noble ME, Endicott JA, Johnson LN. The structural basis for specificity of substrate and recruitment peptides for cyclin-dependent kinases. Nat Cell Biol 1999; 1 : 438-443.

41. Ma J, Arnold HK, Lilly MB, Sears RC, Kraft AS. Negative regulation of Pim-1 protein kinase levels by the B56beta subunit of PP2A. Oncogene 2007; 26: 5145-5153.

42. Rudrabhatla P, Albers W, Pant HC. Peptidyl-prolyl isomerase 1 regulates protein phosphatase 2A-mediated topographic phosphorylation of neurofilament proteins. J Neurosci 2009; 29: 14869-14880.

43. Liou Y-C, Ryo A, Huang H-K, Lu P-J, Bronson R, Fujjmori F et al. Loss of Pin1 function in the mouse causes phenotypes resembling cyclin D1-null phenotypes. Proc Natl Acad Sci USA 2002; 99: 1335-1340.

44. Agami R, Bernards R. Distinct initiation and maintenance mechanisms cooperate to induce G1 cell cycle arrest in response to DNA damage. Cell 2000; 102: 55-66.

45. Woo RA, Poon RYC. Cyclin-dependent kinases and $S$ phase control in mammalian cells. Cell Cycle 2003; 2: 316-324.

46. Corson TW, Gallie BL. One hit, two hits, three hits, more? Genomic changes in the development of retinoblastoma. Genes Chromosomes Cancer 2007; 46: 617-634.

47. Deshpande A, Hinds PW. The retinoblastoma protein in osteoblast differentiation and osteosarcoma. Curr Mol Med 2006; 6: 809-817.

48. Li W, Sanki A, Karim RZ, Thompson JF, Soon Lee C, Zhuang $L$ et al. The role of cell cycle regulatory proteins in the pathogenesis of melanoma. Pathology 2006; 38: 287-301.

49. Wikenheiser-Brokamp KA. Retinoblastoma regulatory pathway in lung cancer. Curr Mol Med 2006; 6: 783-793.

50. Bartkova J, Lukas J, Guldberg P, Alsner J, Kirkin AF, Zeuthen J et al. The p16-cyclin D/Cdk4$\mathrm{pRb}$ pathway as a functional unit frequently altered in melanoma pathogenesis. Cancer Res 1996; 56: 5475-5483.

51. Bao L, Kimzey A, Sauter G, Sowadski JM, Lu KP, Wang D-G. Prevalent overexpression of prolyl isomerase Pin1 in human cancers. Am J Pathol 2004; 164: 1727-1737.

52. Girardini JE, Napoli M, Piazza S, Rustighi A, Marotta C, Radaelli E et al. A Pin1/Mutant p53 Axis Promotes Aggressiveness in Breast Cancer. Cancer Cell 2011; 20: 79-91.

53. Currier N, Solomon SE, Demicco EG, Chang DLF, Farago M, Ying $\mathrm{H}$ et al. Oncogenic signaling pathways activated in DMBA-induced mouse mammary tumors. Toxicol Pathol 2005; 33: 726-737. 
54. Rizzolio F, Caligiuri I, Lucchetti C, Fratamico R, Tomei V, Gallo G et al. Dissecting Pin1 and phospho-pRb regulation. J Cell Physiol 2013; 228: 73-77.

55. Brennan CW, Verhaak RG, McKenna A, Campos B, Noushmehr H, Salama SR et al. The somatic genomic landscape of glioblastoma. Cell 2013; 155: 462-477.

56. Cancer Genome Atlas Network, Comprehensive molecular portraits of human breast tumours. Nature 2012; 490: 61-70.

57. Zhang B, Wang J, Wang $X$, Zhu J, Liu Q, Shi Z et al. Proteogenomic characterization of human colon and rectal cancer. Nature 2014; 513: 382-387.

58. Xiao ZX, Chen J, Levine AJ, Modjtahedi N, Xing J, Sellers WR et al. Interaction between the retinoblastoma protein and the oncoprotein MDM2. Nature 1995; 375 694-698. (c) (i) Cell Death and Disease is an open-access journal published by Nature Publishing Group. This work is licensed under a Creative Commons Attribution 4.0 International Licence. The images or other third party material in this article are included in the article's Creative Commons licence, unless indicated otherwise in the credit line; if the material is not included under the Creative Commons licence, users will need to obtain permission from the licence holder to reproduce the material. To view a copy of this licence, visit http://creativecommons.org/licenses/by/4.0

Supplementary Information accompanies this paper on Cell Death and Disease website (http://www.nature.com/cddis) 